\title{
Proceeding
}

Supplementary Issue: Summer Conferences of Sports Science. Costa Blanca Sports Science Events, 25-26 September 2020. Alicante, Spain.

\section{The influence of healthy habits acquired by school-age adolescents in relation to physical education classes}

\author{
RAFAEL CARACUEL, ROSARIO PADIAL, BEATRIZ TORRES, MAR CEPERO \\ Department of Didactics of Musical, Plastic and Corporal Expression, University of Granada, Spain
}

\begin{abstract}
The main aim of this research is to know the habits of our students due to our concern to educate students about the importance of caring for and improving their health. Students of the First Cycle of ESO of the Centres of the Cordoba regions of the south of the province have fulfilled a survey about their daily habits related to health; In addition, to know the thoughts, beliefs and knowledge of the Physical Education teachers of these students through the conduct of a Discussion Group, in order to learn more about this perspective in relation to Physical Education and Education for Health. Among other data from the analysis and taking into account the food pyramid for these ages, it can be deduced that the students eat few vegetables and that a percentage close to $25 \%$ of the students consumes sweets $3-4$ days a week. It is noteworthy that $59.3 \%$ of boys and $24.1 \%$ of girls regularly do physical activity, apart from the Physical Education class. Regarding the teaching sector, teachers thinks that students are aware of what is advisable to take and what is not; since in schools the diet is changing towards healthier habits, however, the students sometimes eat food that is not conducive to them and they do not even eat. As for hygiene habits, the teachers say that they are consolidated, but the same does not happen with postural habits that they consider not to have correct habits.
\end{abstract}

Keywords: Physical education; Healthy habits; Food; Hygiene; Posture, Middle school.

\section{Cite this article as:}

Caracuel, R., Padial, R., Torres, B., \& Cepero, M. (2020). The influence of healthy habits acquired by school-age adolescents in relation to physical education classes. Journal of Human Sport and Exercise, 15(4proc), S992-S1012. doi:https://doi.org/10.14198/ihse.2020.15.Proc4.02

Corresponding author. Department of Didactics of Musical, Plastic and Corporal Expression, University of Granada, Spain. E-mail: mcepero@ugr.es

Abstract submitted to: Spring Conferences of Sports Science. Costa Blanca Sports Science Events, 19-20 June 2020. Alicante, Spain.

JOURNAL OF HUMAN SPORT \& EXERCISE ISSN 1988-5202

(c) Faculty of Education. University of Alicante

doi:10.14198/jhse.2020.15.Proc4.02 


\section{INTRODUCTION}

Educational and professional Physical Education institutions positively rate the health benefits produced from physical exercise, whilst Physical Education (PE) promotes engagement in physical activity. When such activity is engaged in frequently, positive effects are generated at a physiological, social and psychological level over both the short and long term. As stated by Serrano (2003), "health, as an element of the degree of wellbeing and quality of life achieved, becomes a key element in the social integration of individuals, a goal addressed through education". Thus, from this standpoint, it could be concluded that the purpose of education coincides with the goals of health promotion. In this sense, two relevant concepts are found, those of health and education (clear descriptors of the subject of PE). These concepts are so strongly inter-related that they coexist.

Despite this, levels of regular and appropriate leisure-time physical activity in Spain remain low. This is indicated by survey data from a number of scientific research studies in this context (Benjumea, 2011; Conesa, 2016; Cuesta, 2013; Fernández 2020; Fuentes, 2011; García, 2019; García-Ferrando, 2005; Martínez-Pérez, 2012; Ramos, 2016; Rico, 2017; Vilchez, 2007). This makes clear the importance of continuing to work on this aspect. In our society, lifestyles have experienced a rapid transformation. One of the main challenges of teaching staff, therefore, is to encourage students to engage in physical activity or sport and ensure that they incorporate active and healthy habits into their daily routine. This becomes more necessary everyday due to the high obesity levels which have been largely provoked by sedentary lifestyles (Arribas-Galarraga, 2020).

Scientific evidence shows that the scarcity with which physical activity (PA) is engaged in, alongside sedentary habits in adolescents, represents a behavioural pattern which is perpetuated into adulthood. For this reason, adolescence can be characterised as the period in which an unhealthy and sedentary lifestyle is established (Caracuel, 2016; Chamorro et al., 2018; Muros et al., 2017; Rosa et al., 2019; San Mauro, 2015). The stages encapsulating school age and adolescence become crucial for integrating healthy dietary habits and other lifestyle habits which will persist into later stages. This has repercussions as an important risk factor, not only during this stage but also into adulthood and even old age (Caracuel, Lamas and Cepero, 2019).

With regards to these lifestyle habits in adolescence, Ortega highlighted in 2014 that, in addition to appropriate physical activity (PA) levels, aspects such as the regular consumption of fruits and vegetables, and healthy breakfast habits, amongst others, can also be considered as protective factors in relation to health. Monerero (2012) also highlights sleep as an important element, together with PA and diet, for maintaining the health of individuals. Specifically, this work found that abnormal sleep patterns were conducive to obesity. If we focus on diet as a habit, adolescents' nutrition is often not balanced with respect to the nutrients provided. Instead, the diet tends to be high in fat (35-50\% of total calorific content), with a low polyunsaturated/saturated fatty acid index. The majority of this saturated fat comes from the consumption of meat, smoked sausage, industrial baked goods, fast food and pate, with little coming from milk and derivatives. Likewise, protein and salt consumption is much higher than current recommended levels, whilst current diets also contribute insufficient amounts of complex carbohydrates and fibre due to the low consumption of fruits and vegetables.

As a determinant of health and quality of life, a number of current studies on physical activity in adolescents suggest that weight status and physical activity are related and act as differentiating elements of self-concept during infancy and adolescence (Rosa, García and Carrillo, 2019). This coincides with a large body of work 
which shows that better perceptions of body size and less body dissatisfaction is found in trained adolescents. It is resultantly inevitable that these aforementioned health habits are related with weight. In a similar study with adolescents in the province of Jaen, Ortega (2015) obtained results that lead us to consider that significant levels of body dissatisfaction are found in obese students, or those with tendencies towards obesity.

As a result of this, concern or dissatisfaction with one's body increasingly appears as a health parameter amongst children aged between 10-12 years and 16 years. This is due to the poor relationship found between dietary habits, physical inactivity and weight. This brings with it serious problems in adolescence given that adolescents start to demonstrate concerning nutritional behaviours. In this respect, studies such as those conducted by Ortega et al., (2013) are available in similar populations. These data reflect that more than half of students $(65.5 \%)$ report being dissatisfied with their body. A further study, performed by Menéndez and González (2019), found that students desired to have a slimmer and more athletic body image. This image moves away from the body ideal related with extreme thinness, despite this still being the reference presented in the media.

With regards to sleep, the relationship between rest, activity and posture at the level of health habits is another of the important aspects included in the present study. We found that sleep duration has become a risk factor for childhood obesity. Lack of sleep has been related with weight gain, higher BMI values and a greater likelihood of being overweight or obese. Carrillo-Larco et al., (2014) showed that obesity was 64\% more frequent amongst children who slept for only a short duration (Bagley and El-Sheikh, 2013; Chen, Beydoun and Wang, 2008). Good education around postural health has also become crucial in the school setting. This is because it represents a developmental stage characterised by the formation and growth of bone structures. A large number of students suffer damage to their spine due to assuming a poor posture when sat in class, performing physical activities incorrectly, or carrying excess weight in their school backpacks. Generally, back pain is also associated with students who have little muscle tone and engage in little physical activity. Physical Education classes are, therefore, important for providing appropriate education around good posture to adolescent students (Chacón et al, 2018).

As with the majority of healthy and non-healthy life habits established during infancy and adolescence, the development of effective health promotion and disease prevention strategies for children and adolescents appears to be critical, not only in relation to weight status, but also to present and future health. Thus, it is recommended to instil in students the importance of being healthy for reasons beyond weight control, whilst also conducting more studies which utilise multi-factorial analysis of habits. Many studies exist although a particularly relevant one to cite here is that carried out by San Mauro (2015). This study concluded that a minimum of one hour of exercise a day should be established as a basic recommendation, with this rising to two hours a day in cases of high sedentary habits. Sedentary habits consider hours spent using a computer, other consoles and the television.

With regards to the relationship between adherence to these habits and PE classes, research studies show that the Physical Education teacher themselves, in addition to the subject of PE, is an important figure for achieving such habits (Tobar et al., 2019). It is highlighted that at these ages, content blocks of games and sports, health, and the physical condition, play a fundamental role on students' likes and desires for engaging in physical activity in Physical Education classes. In the majority of cases, this is reflected in students' lifestyles. In other words, their attachment to the subject of PE and subsequent success is directly related with physical activity engagement outside of the classroom (Valencia-Peris and Mora, 2018). Further, clear improvements are seen to students' self-esteem, self-concept and perceptions, whilst also improving values 
related to effort, respect, teamwork, sportsperson ship and health at school. Such content should, therefore, be worked on due to its relevance for all of the personality areas of students. Further, it has also been indicated that values acquired through physical activity or sport engagement at school, specifically in Physical Education classes, positively impact social relationships and responsibility amongst students (Martínez et al., 2013). Although, with regards to teachers' perceptions of PE, various studies reported by Caracuel and Guerreiro (2018) indicate that the majority of students have a hazy concept of health. On the other hand, they have a clear idea about those indicators that are beneficial and those that are not. Further, they have well established knowledge and safety habits when engaging in physical activity or sport. Finally, it has been detected that it is difficult to modify dietary behaviours if changes to family and social contexts are not promoted at the same time (Benítez, 2017).

In relation to that described above, concern is warranted on behalf of Physical Education professionals, teachers and trainers. A clear need is shown to raise awareness amongst students of the importance of caring for and improving health through these habits. As stated by Cimarro (2014): "as educators we are obliged to promote the development of appropriate physical activity and health plans, in order to help our students, perceive and value the benefits of regular physical activity, correct nutrition, sufficient rest and correct personal hygiene". To this end, the present research study was conducted with the main objective of uncovering the habits of secondary school students from the southern province of Cordoba, Spain. This is important because if healthy practice is established in the adolescent stage and required protection measures are taken against health risks, we will be able to prevent future health problems when adult age is reached. Consequently, we will positively help society in general and, particularly, health infrastructures.

In order to achieve the aforementioned objective, adolescent students from the southern region of Cordoba were interviewed. Students were enrolled on the first year of compulsory secondary education and were asked about their habits in relation to health. Further, group discussions with teachers were performed to collect data on students' thoughts, beliefs and knowledge in respect to Physical Education and education for health.

\section{MATERIAL AND METHODS}

\section{Study design}

With the aim of meeting the proposed objectives a research design was used which combined quantitative and qualitative research techniques. These techniques included a closed questionnaire which collected data via a quantitative approach. This enabled us to achieve a broad sample of the target population and, in this way, quantify results and be able to generalise them to a certain extent. On the other hand, at the qualitative level a group discussion was conducted. We sought to combine methodologies in a way that permitted us to deepen further our understanding of the quantitative data and provide an interpretive focus (Cimarro, 2014; Cuesta, 2013; Martínez-Pérez, 2012; Ovalle, 2011; Rodríguez-Bailón, 2012). The present work was carried out in a specific population and setting. It collected data from each participant at only one time-point and is, therefore, considered to be a cross-sectional study. In the same way, the present research could also be considered as "descriptive and interpretive", according to the classification provided by Latorre, Del Rincón and Arnal (2003). The aim of the approach taken was to collect and analyse information in order to be able to later interpret the reality regarding the beliefs, thoughts, knowledge, attitudes and habits of sampled students in relation to health habits. This information will then be used to complement the qualitative data obtained about the perceptions offered by Physical Education teachers in the region in which the study was conducted. 


\section{Context}

The context in which the present research was conducted was the province of Cordoba. Cordoba is situated to the south of the Spanish mainland, in the central northern region of the autonomous community of Andalusia. Specifically, the study was administered in the educational centres of the following municipal regions: "Southern countryside [Campiña Sur]", "Sub-Baetic area [Subbética]" and "Baena countryside [Campiña de Baena]". With regards to the family, cultural, economic and social setting, we can say that homogenous levels are seen as participants belong to towns from the same region.

\section{Participants}

The sampling method employed to select individuals from the sample was non-probabilistic and is denominated "accidental or convenience sampling". The method is described by Carrasco and Calderero (2000) and applied selection criteria within first- and second-year secondary school students. In total, we obtained results from the questionnaires of 526 students from six educational centres, aged between 12 and 15 years. The sample was composed of 325 first year secondary school students (155 males and 170 females) and 201 second year secondary school students (93 males and 108 females).

Table 1. Distribution of the sample by centres, course and gender.

\begin{tabular}{|c|c|c|c|c|c|c|c|c|}
\hline \multirow[t]{2}{*}{ Centre } & \multirow[t]{2}{*}{ Location } & \multicolumn{2}{|c|}{$\begin{array}{c}1^{\text {st }} \text { Course } \\
\text { ESO }\end{array}$} & \multirow{2}{*}{$\begin{array}{c}\text { Total } \\
1^{\text {st }}\end{array}$} & \multicolumn{2}{|c|}{$\begin{array}{c}2^{\text {nd }} \text { Course } \\
\text { ESO }\end{array}$} & \multirow{2}{*}{$\begin{array}{c}\text { Total } \\
2^{\text {nd }}\end{array}$} & \multirow[t]{2}{*}{ Total } \\
\hline & & Boys & Girls & & Boys & Girls & & \\
\hline IES Ategua & Castro del Río & 0 & 0 & 0 & 16 & 24 & 40 & 40 \\
\hline \multirow{4}{*}{$\begin{array}{l}\text { IES Inca Garcilaso } \\
\text { IES Luis Carrillo de } \\
\text { Sotomayor } \\
\text { IES Marqués de } \\
\text { Comares } \\
\text { CEIP San José }\end{array}$} & Montilla & 33 & 26 & 59 & 22 & 21 & 43 & 102 \\
\hline & Baena & 29 & 39 & 68 & 28 & 39 & 67 & 135 \\
\hline & Lucena & 32 & 24 & 56 & 27 & 24 & 51 & 107 \\
\hline & \multirow{2}{*}{$\begin{array}{l}\text { Palenciana } \\
\text { Priego de } \\
\text { Córdoba }\end{array}$} & 22 & 24 & 46 & 0 & 0 & 0 & 46 \\
\hline IES Fernando III & & 39 & 57 & 96 & 0 & 0 & 0 & 96 \\
\hline Totals & & 155 & 170 & 325 & 93 & 108 & 201 & 526 \\
\hline
\end{tabular}

Table 2. Distribution of the sample by age, grade and gender.

\begin{tabular}{|c|c|c|c|c|c|c|c|c|c|c|c|c|}
\hline \multirow{4}{*}{ Years } & \multicolumn{12}{|c|}{ Course/Gender } \\
\hline & \multicolumn{4}{|c|}{ 1st ESO } & \multicolumn{4}{|c|}{$2^{\text {nd }} \mathrm{ESO}$} & \multicolumn{4}{|c|}{ TOTALS } \\
\hline & \multicolumn{2}{|c|}{ Boys } & \multicolumn{2}{|c|}{ Girls } & \multicolumn{2}{|c|}{ Boys } & \multicolumn{2}{|c|}{ Girls } & \multicolumn{2}{|c|}{ Boys } & \multicolumn{2}{|c|}{ Girls } \\
\hline & $\mathrm{N}$ & $\%$ & $\mathrm{~N}$ & $\%$ & $\mathrm{~N}$ & $\%$ & $\mathrm{~N}$ & $\%$ & $\mathrm{~N}$ & $\%$ & $\mathrm{~N}$ & $\%$ \\
\hline 12 & 68 & 43.9 & 97 & 57.1 & 0 & .0 & 0 & .0 & 68 & 27.4 & 97 & 34.9 \\
\hline 13 & 56 & 36.1 & 52 & 30.6 & 25 & 26.9 & 37 & 34.3 & 81 & 32.7 & 89 & 32.0 \\
\hline 14 & 29 & 18.7 & 17 & 10.0 & 47 & 50.5 & 53 & 49.1 & 76 & 30.6 & 70 & 25.2 \\
\hline 15 & 2 & 1.3 & 4 & 2.4 & 21 & 22.6 & 18 & 16.7 & 23 & 9.3 & 22 & 7.9 \\
\hline Totals & 155 & 100.0 & 170 & 100.0 & 93 & 100.0 & 108 & 100.0 & 248 & 100.0 & 278 & 100.0 \\
\hline
\end{tabular}

With regards to the qualitative sample, the same characteristics were seen. A group of eight teachers/specialists of Physical Education were involved who had a Bachelor degree in Physical Activity and Sport. Of these, 4 also possessed a PhD. All teachers were practicing in the centres at which the research was carried out. These centres included the centres of IES Ategua, IES Inca Garcilaso, IES Luis Carrillo de 
Sotomayor, IES Marqués de Comares, CEIP San José and IES Fernando III. Participating students came from the same centres.

Table 3. Distribution of the teaching staff sample.

\begin{tabular}{lllc}
\hline $\mathbf{N}^{0}$ Teacher & Gender & Place & Years of experience \\
\hline Teacher 1 & Man & Subbética & 14 \\
Teacher 2 & Man & Subbética & 18 \\
Teacher 3 & Women & Sur & 9 \\
Teacher 4 & Man & Sur & 6 \\
Teacher 5 & Women & Sur & 13 \\
Teacher 6 & Man & Guadajoz-Baena & 5 \\
Teacher 7 & Man & Guadajoz-Baena & 20 \\
Teacher 8 & Man & Subbética & 24 \\
\hline
\end{tabular}

\section{Measures and Procedures}

Data collection techniques and instruments included the HAVISAES questionnaire of healthy life habits in adolescent students (see Appendix. Table 4). This was created and validated for the present research by Cimarro (2014). First, a seminar was created with the aim of designing and applying the questionnaire. This development was based on existing literature (Colas and Buendia, 1996; Goetz and Lecompte, 1988; Taylor and Bogdan, (1986) and on previously conducted research by the research group, for example Fuentes (2011), Collado, Estévez, Cuesta, Ortega, etc... These previous works collected information relative to the dimensions formulated in the objectives of the present study. Next, we will define the included dimensions, mode of application, analysis and pertinent revisions. Following the initial development of the questionnaires and their analysis within the seminar, questionnaires were validated by an expert panel according to broadly used criteria in the existing literature (8 expert teachers from the University of Granada, Jaen and Malaga) and a first pilot administration was carried out. Finally, a questionnaire was produced which comprised 40 closed and categorical questions. This sought to make obtained responses more exhaustive.

Another technique employed was group discussion with Physical Education teachers from the centres at which the questionnaire was administered. In accordance with Fuentes (2011), Ibáñez (2008), Palomares (2003) and Posadas (2009), three basic activities were performed to generate the discussion group: participant selection, development of an action plan, and interpretation and analysis of meetings. The protocol was based on open questions and was elaborated by members of the HUM-727 Research Group during a meeting held on the 27th of April 2015. Recommendations laid out by Suárez (2005) and Callejo (2001) regarding the advantages of, and recommendations for, the administration of self-completed questionnaires provided a basis. These recommendations were later adapted to the present objectives.

The general questionnaires posed by teaching staff are listed in Table 5 questions posed in the group discussion are presented in the Appendix.

Finally, we discuss data handling. In order to examine the information produced by the questionnaires, the software SPSS was used in its version 20.0. Further, the program Nudist vivo, version 8.0., was used to analyse the data obtained through the discussion group. This enabled later triangulation of these data. 


\section{RESULTS}

Through the application of the aforementioned data collection instruments and subsequent analysis, interesting data emerged about the parameters that relate to the healthy lifestyle habits of adolescent students. These parameters included engagement in extra-curricular physical activity or sport, dietary and postural habits, and rest. Triangulated results obtained from the two utilised instruments are presented.

With regards to engagement in extra-curricular physical activity, responses indicate that $59.3 \%$ of male students report frequently engaging in activity, with $22 \%$ reporting engaging "sometimes". On the other hand, females selected the response option of "sometimes" to a greater extent, with $45.7 \%$ reporting this option. All participants acknowledged that physical activity engagement contributed to a better quality of life.
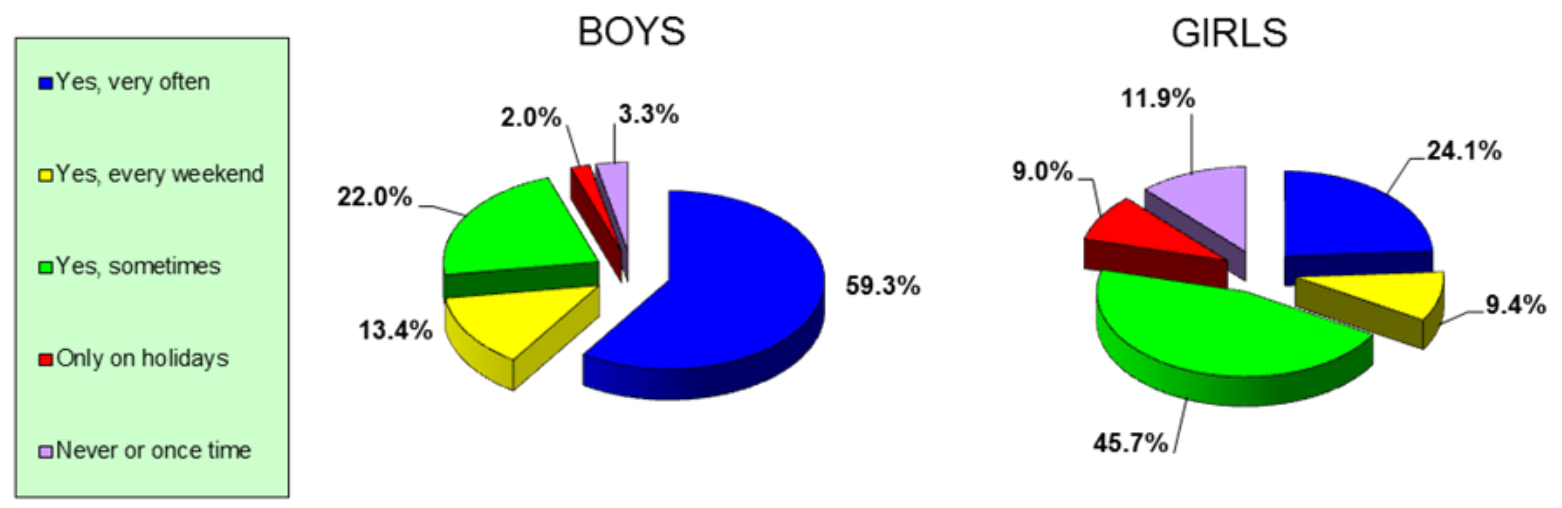

Figure 1. Engagement in extra-curricular physical activity.

In the discussion group, opinions of teaching staff reinforced the statements given by students in relation to physical activity engagement. In this sense, the majority of participants explained that the majority of their students clearly acknowledged the direct relationship between physical activity and health. For instance, teacher 8 commented:

They understand that engaging in physical exercise such as through games, sport or simple physical exercise itself makes them healthy and strong. Thus, it offers a route for obtaining good health.

Teacher 8 (031-033) PCD

If we now address the habits followed by students at the time of engaging in physical activity or sport, the majority of participants reported performing a warm-up beforehand, with $47.5 \%$ of males and $41.7 \%$ of females reporting this practice. Nonetheless, with regards to common habits when engaging in physical activity, fewer individuals reported stretching prior to practice. Specifically, 35.5\% of surveyed female students reported stretching relative to $40.4 \%$ of males. Another fundamental aspect at the time of engaging in physical exercise is the use of sportswear. This habit has been acquired by the majority of students in the present sample, being reported by $87.3 \%$ of male students and $85.9 \%$ of female students. With regards to hydration during engagement, the majority of both males and females indicated that they frequently hydrated, specifically $50.2 \%$ and $44.7 \%$ of males and females, respectively. Similarly, the habit of grooming oneself after finishing a sport session emerged as another necessary habit, with this being carried out by $77 \%$ of participating male students and $84.4 \%$ of females. 
It is important to note that Physical Education teachers corroborate the statements given by students in this respect. Concretely, teachers expressed that personal hygiene habits had been fully acquired by the students of the regions in which the research was developed. As an example, teacher 1 commented:

Personal hygiene is one thing I think we have pretty much mastered, at the moment, there aren't a great number of students who don't have acceptable hygiene, it's really complicated.

Teacher 1 (197-199) HHP.

On the other hand, the same cannot be said regarding postural habits. Participating teaching staff were clear that their students do not exhibit correct habits with regards to their posture. They referred to the lack of tools to correct poor posture, in addition to stating that students did not attribute any importance to this habit. In this way, teacher 5 indicated:

And then I am always pushing postural hygiene in the sense that I teach them on the first day of class how you have to sit in class and I at least ask them while I am explaining the session how they think they should be sat correctly. It is true that they are a lot of hours and as Gustavo says, the chairs and tables are not prepared for children. You might even see a child with their legs dangling. Thus, obviously, they cannot be well sat, or the table is too small for them, so, we have these added things here and there that make this postural hygiene much more difficult.

Teacher 5 (273-281) HAPI.

In considering the dietary habits of students from the southern regions of Cordoba, the results obtained provide cause for concern with regards to the fact that the most commonly reported statement in relation to fruit and vegetable consumption was "1-2 times a week". This was the case in both males (36.4\%) and in females (35.3\%). This contrasts with the consumption of sweets, with the most commonly provided response being the option of "3-4 times a week", with percentages of $29.3 \%$ and $30.9 \%$ in male and female students, respectively.

For their part, teachers commented that students are aware of the theoretical benefits to the human body of having a healthy diet. Despite this, the practice of such habits is not completely entrenched. In other words, teachers stated to us that their students know what is advisable to eat and what should not be consumed, despite the fact that they did not always adhere to this advice. Further, teachers indicated that this trend is changing thanks to actions being carried out within the educational centres towards promoting the consumption of healthier products. In this sense, teacher 3 stated:

I think that with the topic of diet and nutrition because many years have been spent working and on plan, there are a lot of local government plans... I don't know, they bear fruit, nutritional programs. Whether you want it or not the parents are also really aware of this topic, and at breaktime, at least I do at my centre, every day they bring something different, not just the sandwich, not just the dessert, but they alternate. So, from my point of view in the centre that I am at, the students have it more ingrained, let's say, in their life the topic of nutrition and it being varied, sure there will be a bit of everything, they like some things and not others, but I see it worse in the town, as it is a rural town. Teacher 3 (161-169) HAPD.

Finally, we consider the data collected relative to work-rest habits. Students reported an average of between 6-8 hours of sleep a night. Whilst females reported around half an hour more than males, actual sleep duration achieved was below recommended levels in both cases. Finally, with regards to the perceptions 
shared by teachers, they consider that there is a lack of balance. Teaching staff are certain that students fall short when it comes to getting enough rest. Although their responses are politically correct, they report noting tiredness in class, a lack of sleep and poor concentration due to this lack of balance.

\section{DISCUSSION}

The data obtained from the present research work carried out and described above are related to other scientific works conducted in similar situations. In all of these works, it is evident that both adolescent students and teaching staff acknowledge the positive influence of physical activity engagement and healthy lifestyle habits on health.

In relation to physical activity engagement, many authors propose attitudes that favour active travel as a way of consolidating healthy habits. Active travel begins by moving from one's place of residence and ends upon arrival to the educational centre. Chillón et al., (2011), states that despite the fact that, in the present day, the challenges posed by distance, timetables and safety must be overcome, arriving to school on foot is once again becoming a popular option for students from the perspective of achieving a healthy lifestyle. Further, it leads to greater happiness and wellbeing (Martínez-López and Ruíz-Ariza, De la Torre-Cruz, RedecillasPeiró, 2015), and a better physical condition (Villa-González, Ruíz and Chillón 2015) amongst students.

Both students and teachers are clear that physical activity is one of the variables that most influences health, as highlighted by Hendricks et al. (2007). Despite this, high levels of sedentary behaviour and a lack of physical activity is often found due to numerous factors which are dependent on the child's environment. It has been demonstrated that it is easier to promote the acquisition of healthy habits during the life stage being experienced by students at the time of the present study. This is in stark contrast to the difficulty of attempting to modify structured life habits in later adult life. In this sense, we echo assertions made by Lohman and Going (2006) about the importance of physical education at these ages.

Shifting focus to the healthy habits seen when engaging in physical activity itself, Álvarez and Martínez (2019) indicate that conducting a warm-up is a crucial and fundamental part of Physical Education sessions. Due to the fact that this habit is instilled in these classes, it is typically acquired at school and then later applied by students when engaging in sport in their free-time. Along these lines, the present study confirmed that students warm up before engaging in physical exercise. In this same sense, we corroborate the statement made by Salazar Martínez (2007) that: "it would be unthinkable to start a class at a certain intensity without performing some prior activities. This importance is based on the principal function of preventing injuries to students, whilst also creating a predisposition towards activity". Further, we must not forget the benefits produced by warming up at a physiological level, as stated by Rabadán et al. (2007).

Another important and necessary habit at the time of playing sport is to stretch well. Zueck et al. (2020) argue that in order to promote the acquisition and maintenance of this healthy habit, it is necessary to perform stretches and a warm-up during physical education sessions. This will also awake student's interest in the activity. In addition, the present research is related with results extracted from the scientific work of Espejo (2007). This considers that "in the present day, the technique of stretching provides a therapeutic, preventative and physical work tool for both elite performance and for the recreational sports person". From this, the need is outlined to not forget to stretch when performing leisure-time physical activity.

It is also crucial to wear appropriate sports clothing. The majority of students in the present sample confirmed that they used such clothing when performing physical exercise. In this sense, the present work is related 
with considerations made by Garrido (2014) and Esteban (2011). This author highlighted the need for appropriate sportswear, even when engaging in simple exercise or games. Aguilar et al. (2019) indicate that students do not tend to bring sports clothing to physical education classes and that this constitutes an important problem in session development. Above all, we agree with that outlined by Latorre (2008) that we would be putting the students themselves at risk if they lacked the correct clothing or footwear. For this reason, it is hugely positive that both the students and teaching staff involved in the present research confirmed that Physical Education sessions at the studied educational sessions were performed using sports clothing.

With regards to hydration, we agree with that posited by Mesa et al. (2002) who considered that sport participants should drink sufficient liquid before, during and after physical activity. According to these authors, "the drink should be a solution composed of water, electrolytes and carbohydrates in sufficient quantities to guarantee a complete and effective replenishment of lost water, electrolytes and energy". The statement of Casa (2020) coincides with opinions extracted from the discussion group conducted in the present study. This author indicates that good hydration is necessary to carry out healthy physical activity practice. Participating teaching staff also indicated that this habit has been consolidated.

Data obtained in the present research study in relation to grooming habits after performing exercise are in accordance with those also reported by Fuentes (2011). In this previously conducted study with students aged between 12 and 14 years from the city of Jerez (Cadiz), it was also revealed that female students displayed better personal hygiene habits. With regards to posture, warnings given by González (2000) should be considered with regards to the increase in lower back pain and spinal disorders experienced within the school population. For this reason, it is important to administer certain interventions targeting correct development, mainly in attitudes towards posture.

Next, we consider the type of diet that should be followed, or, in other words, dietary habits. Specifically, we focus on the consumption of two types of contrasting diets due to its healthy and unhealthy components, vegetables and sweets. On this topic, it is interesting to highlight data produced in the study conducted by Gómez Candela et al. (2007). This study examined data extracted from 2,078 surveys completed by adolescents from 19 Spanish provinces. As with that found in the present study, students exhibited a high consumption of sweets, with $4.5 \%$ of respondents stating that they consumed sweets on a daily basis. In the same sense, the National Survey of Dietary Habits in Infancy and Adolescence (Enkid Study, 1998-2000) examined dietary habits in a relevant population. More than 3,500 individuals aged between 2 and 24 years participated in this survey. Outcomes indicated an insufficient consumption of fruits and vegetables amongst children and adolescents, mirroring outcomes obtained in the present sample.

Finally, the most concerning outcomes in the present research were obtained in relation to work-rest habits. Students state that they have an average of between 6-8 hours nightly sleep, with this being below recommended levels. Present results coincide with the perceptions of teaching staff who consider that students get little sleep. Whilst their responses were politically correct, they are aware of what truly takes place as they notice tiredness, lack of sleep and poor concentration in classes. These outcomes are due to the aforementioned lack of balance between work and sleep. We know that adolescents need to sleep between eight and 10 hours a night in order to achieve positive wellbeing, yet $93.5 \%$ of young people do not even manage seven hours (health [salud], 2020). This lack of sleep is tightly linked with a decrease in cognitive performance, obesity risk and depression. During the weekend it seems that average sleep duration decreases further by at least one hour, this lack of sleep can largely be blamed on a greater use of social 
networks. Thus, adolescents' broader behavioural habits have a direct influence on their sleep habits (Puerto et al., 2015).

\section{CONCLUSIONS}

Both the school age and adolescence are crucial stages for establishing dietary habits and other lifestyle habits which will persist into later life stages. The habits ultimately instilled will, therefore, have repercussions throughout life, whilst the subject of PE and related teaching staff play a hugely important role.

In the present research work, we determined that adolescent students sampled from southern regions of the province of Cordoba were aware of correct dietary consumption habits. Nevertheless, their consumption of fruits and vegetables is below that recommended for healthy portions, whilst, in contrast, consumption of foods with sugar, saturated fats and sweets was above recommended rates. This is despite the fact that teaching staff rationalise that students are aware of good nutrition and alimentation, and of which foods it is advised that they do and do not consume. It seems that students do not always act on appropriate knowledge. With regards to hydration, students hydrate appropriately. They drink the appropriate volume for their age and meet hydration needs following physical activity.

In addition, it should be highlighted that students have acquired grooming and performance habits in PE classes and during PA engagement. Students always wear appropriate clothing when involved in such activity and normally groom themselves when they are finished. This fact was confirmed by the teachers themselves who conclusively agreed that this habit was well ingrained in their students. With regards to sports practice, a warm-up was similarly seen as a commonly followed habit. Students were also clear of the importance of stretching and regularly engaged in this practice following sporting practice. Finally, with regards to attitudes towards postural habits, teachers stated that they did not perceive students to have correct postural habits. This was despite the fact that they are often talked about in class and students tend to know what appropriate postural habits are.

With regards to habits pertaining to the work-rest balance, equilibrium is not achieved. Teaching staff state clearly that students fail when it comes to getting enough rest. Whilst they stick to politically correct responses, tiredness, a lack of sleep and poor concentration are noted in classes due to this imbalance.

As professionals exercising in Physical Education, we conclude that appropriate actions must be developed. Such actions should continue to promote positive attitudes and values through this subject, impacting upon the acquisition, improvement and maintenance of healthy habits which will last throughout life.

In conclusion, due to the transcendence of this work in the school, teaching and family setting, it is important to highlight some of the interesting didactic implications of the present results. Of these, those related with educational centres and families are particularly relevant. From all of these settings, particularly from educational centres, it is necessary to attempt to instil healthy habits in students through plans and projects. Some such actions are managing to reverse these trends towards favouring more healthy habits. Examples that could be used include those put in place by relevant institutions such as the recent Promotion Strategy for a Healthy Life in Andalusia. Further, it is necessary to take advantage of the diffusion channels made available to centres via their platforms, websites, and so on. These should be made use of two convoke, organise, and carry out workshops for parents and students targeting alimentation, cooking, posture, etc... Further, actions should occur in coordination with PE departments in order to create active travel plans for getting to school and active breaktimes. It must be made clear that this objective should be common for all 
teaching staff. For this reason, staff should promote the design of integrated tasks amongst themselves, in which the central topics relate to Education for Health.

As another important aspect, family is the fundamental unit of society. It finds itself in continuous interaction with the social, cultural and natural environment and so should form the basic unit for intervention. For this, we propose actions within the family setting to target the health of children. The aim of this is to modify determined action guidelines within the home so that they are targeted towards influencing young people as an effective strategy for improving health. Actions, workshops and talks should be organised for families in order to help them to reflect on the dietary and PA habits followed at home. In cases where such habits are not appropriate, tools should be provided to change them. Such tools include information provision, training to acquire knowledge about healthy lifestyle habits and teaching parents to serve as role models for their children. The latter of these - role modelling - is the most effective learning strategy for promoting adherence to any habit or learning.

With regards to the media and the role it plays on the implications for institutions and family, it must promote healthy lifestyles through advertisements that encourage adolescents to eat healthily and regularly engage in physical activity. Such publicity is powerful for raising awareness. Other suggestions of actions to be conducted with teachers, families and, even, the students themselves, include review workshops to give PA and dietary information throughout the day on different television channels at different time-slots, including infant time-slots.

\section{REFERENCES}

Aguilar, G. F., Grau, M. P., \& Prat, S. S. (2019). El profesorado de educación física y su visión sobre los conflictos en una escuela multicultural. Educar, 55(1), 183-200. https://doi.org/10.5565/rev/educar.975

Alarcon, A., \& Jannier, D. (2019). Hábitos saludables a partir de la educación física. Tesis Doctoral: Universidad de Granada.

Álvarez, C. S., \& Martínez, A. V. (2019). Calentamiento para la actividad físico-deportiva. Sus fundamentos metodológicos dentro del proceso de enseñanza. Panorama Cuba y Salud, 14(1), 35.

Bagley EJ \& El-Sheikh M. (2013). Familial risk moderates the association between sleep and ZBMI in children. J Pediatr Psychol; 38: 775-784. https://doi.org/10.1093/ipepsy/jist031

Benítez, M. B. (2017). Prevención de la obesidad y los trastornos de la conducta alimentaria. Papel del dietista nutricionista. Trastornos de la conducta alimentaria, 25, 2683-2765.

Benjumea, M. A. (2011). Motivación del alumnado de segundo ciclo de Educación Secundaria de la comarca de la Vega Alta de Granada, en Educación Física escolar y en las actividades físicodeportivas extraescolares. Tesis Doctoral: Universidad de Granada.

Caracuel, R. (2016). Influencia de la educación física en los hábitos saludables del alumnado de primer ciclo de educación secundaria en centros de las comarcas del sur de Córdoba. Tesis Doctoral: Universidad de Granada.

Callejo, J. (2001). El grupo de discusión: introducción a una práctica de investigación. Barcelona: Ariel Prácticum.

Caracuel, R., \& Guerreiro, A. (2018). Percepción del alumnado de primer ciclo de educación secundaria sobre su salud desde la perspectiva del profesorado. Conhecimento \& Diversidade, 10(21), 25-39. https://doi.org/10.18316/rcd.v10i21.4711 
Caracuel, R., Torres, B., Padial, R., \& Cepero, M. (2018). La escuela como agente de socialización y su influencia en la adquisición y mantenimiento de hábitos saludables y no saludables. Education, Sport, Health and Physical Activity (ESHPA): International Journal, 2(2), 207-216.

Caracuel, R., Lamas, J.L., \& Cepero, M. (2019). La importancia de los hábitos de práctica de actividad física, adquiridos en edades tempranas para mantenerlos y favorecer un envejecimiento activo de excelencia. II Conferencia Internacional Envelhecimento Ativo e Educação - Universidade do Algarve.

Carrasco, J. \& Calderero, J. (2000). Aprendo a investigar en educación. Madrid: Rialp.

Carrillo-Larco, RM, Bernabé-Ortiz, A., \& Miranda, J.J. (2014). Short Sleep Duration and Childhood Obesity: Cross-Sectional Analysis in Peru and Patterns in Four Developing Countries. PLoS One, 9 (11), e112433. https://doi.org/10.1371/journal.pone.0112433

CASA, T.A.F.E. (2020). Guías de trabajo Área de Educación Física, Recreación y Deporte.

Chacón, F., Ubago, J. L., Guardia, J. L., Padial, R. \& Cepero, M. (2018). Educación e higiene postural en el ámbito de la Educación Física: papel del maestro en la prevención de lesiones: revisión sistemática. Retos: nuevas tendencias en educación física, deportes y recreación, 34, 8. https://doi.org/10.47197/retos.v0i34.54319

Chacón-Cuberos, R., Zurita-Ortega, F., Martínez-Martínez, A., Olmedo-Moreno, E., Castro-Sánchez, \& M. (2018). Adherence to the Mediterranean diet is related to healthy habits, learning processes, and academic achievement in adolescents: A cross sectional study. Nutrients, 10(11), 1566. https://doi.org/10.3390/nu10111566

Chamorro, R., Farias, R. \& Peirano, P. (2018). Circadian rhythms, eating patterns, and sleep: A focus on obesity. Revista Chilena de nutrición. 45(3), 285-292. https://doi.org/10.4067/s0717$\underline{75182018000400285}$

Chen X, Beydoun M. A., \& Wang Y. (2008). Is sleep duration associated with childhood obesity? A systematic review and meta-analysis. Obesity, 16: 265-274. https://doi.org/10.1038/oby.2007.63

Chillón, P., Gottrand, F., Ortega, F. B., González-Gross, M., Ruiz, J. R., Ward, D. S., ..., \& Molnar, D. (2011). Active Commuting and Physical Activity in Adolescents From Europe: Results From the HELENA Study. Pediatric Exercise Science, 23(2), 207-217. https://doi.org/10.1123/pes.23.2.207

Cimarro, J. (2014). Adquisición y mantenimiento de hábitos de vida saludables en los escolares del tercer ciclo de Educación Primaria en centros de las comarcas del Sur de Córdoba, y la influencia de la Educación Física sobre ellos. Tesis Doctoral: Universidad de Granada.

Conesa, M. D., \& Juan, F. R. (2016). Clima motivacional en Educación Física y actividad físico-deportiva en el tiempo libre en alumnado de España, Costa Rica y México. Retos: nuevas tendencias en educación física, deporte y recreación, 29, 195-200.

Cuesta, J. M. (2013). Relación entre la insatisfacción con la imagen corporal, la autoestima, el autoconcepto físico y la composición corporal, en el alumnado de tercer ciclo de Educación Primaria de la ciudad de Motril. Tesis Doctoral: Universidad de Granada.

Denzin, N.K. \& Licoln, Y. (2000). Handbook of Qualitative reserchs. London: Sage.

Estudio Enkid (1998-2000). Med Clin, 121, 725-732.

Estévez, M.; Muros, J.J.; Torres, B., Pradas, F., Zurita, F., \& Cepero, M. (2015). Influencia de la composición corporal y la aceptación por las clases de educación física sobre la autoestima de niños de 14-16 años de Alicante, España. Nutrición Hospitalaria, 31 (4):1519-1524.

Fernández, S. B., Juste, M. R. P., Pino, I. P., \& Trabazo, M. R. L. (2020). Evaluación de los hábitos de alimentación y actividad física en escolares gallegos. Nutrición hospitalaria: Órgano oficial de la Sociedad española de nutrición parenteral y enteral, 37(1), 93-100. 
Fischetti, F., Latino, F., Cataldi, S., \& Greco, G. (2020). Gender differences in body image dissatisfaction: The role of physical education and sport Journal of Human Sport and Exercise, 15(2): 241-250. https://doi.org/10.14198/jhse.2020.152.01

Fuentes, E. (2011). Adquisición y mantenimiento de hábitos de vida saludables en los escolares de primer ciclo de Educación Secundaria Obligatoria de Jerez de la Frontera (Cádiz). Tesis Doctoral: Universidad de Granada.

Galarraga, S. A., \& De Cos, I. L. (2020). El modelo de enseñanza personalizada (MEP) como promotor de hábitos saludables. Revista interuniversitaria de formación del profesorado, (95), 69-84.

García, P. S., \& González, V. B. (2019). Niveles de actividad física y sedentarismo en escolares de $3^{\circ}$ y $4^{0}$ de Educación Primaria. EmasF: Revista digital de educación física, (56), 119-131.

García-Ferrando, M. (2005). Encuesta sobre hábitos deportivos de los españoles. Madrid: CIS.

Garrido, A. L. (2014). La práctica de la actividad física y hábitos de salud de los futuros maestro de educación primaria de la universidad de Barcelona. Un estudio sobra la incidencia de la Educación Física vivida en la E.S.O. Tesis doctoral: Universidad de Barcelona.

Goetz, J. \& Lecompte, M. (1988). Etnografía y diseño cualitativo en investigación educativa. Madrid: Morata.

Gómez-Candela, T.; Lourenço-Nogueira, V.; Loria-Kohen, M.; Marín-Caro, J.R.; Martínez-Álvarez, C.; Pérez-Rodrigo, C.; Polanco, I., et al. (2007). Análisis de las encuestas de hábitos alimentarios realizadas en población escolar durante la 4ª edición del Día Nacional de la Nutrición (DNN) 2005. Nutr Clin Diet Hosp, 1, Vol. XXVII/24.

González de Mesa, C. (2000). La Educación para la cultura del ocio en la formación del profesorado de Educación Física. En Facultad de Educación (Ed.) XVI Congreso Nacional de Educación Física. Facultades de Educación y Escuelas de Magisterio. (65-72). Badajoz: Indugrafic.

Grao-Cruces, A., Nuviala, A., Fernández-Martínez, A., \& Pérez-Turpin, J. A. (2014). Association of physical self-concept with physical activity, life satisfaction and Mediterranean diet in adolescents. Kinesiology, 46(1), 3-11.

Hendricks, M.K., Goeiman, H., \& Dhansay, A. (2007). Food-based dietary guidelines and nutrition interventions for children at primary healthcare facilities in South Africa. Maternal y Child Nutrition, 3, 251-258. https://doi.org/10.1111/j.1740-8709.2007.00110.x

Ibáñez-Martí, C. (2008). Educación para la salud en la escuela: una metodología diferente. Salud Pública y algo más. Retrieved from: http://www.madrimasd.org/blogs/salud_publica/2008/09/15/100908

Latorre, A., Del Rincón, D., \& Arnal, J. (2003). Bases metodológicas de la investigación educativa. Barcelona: Hurtado Ediciones.

Lohman, T.G., \& Going, S.B. (2006). Body composition assessment for development of an international growth standard for pre-adolescence and adolescent children. Food Nutr Bull, 27: S314-25. https://doi.org/10.1177/15648265060274S512

Martínez, R., Cepero, M., Collado, D., Padial, R., Pérez, A., \& Palomares, J. (2013). Adquisición de valores y actitudes mediante el juego y el deporte en educación física, en educación secundaria. Journal of Sport \& Health Research, 6 (3).

Martínez-Pérez, R. (2012). Transmisión y adquisición de valores y actitudes a través del Bloque de Contenidos de Juegos y Deportes en el alumnado de Segundo Ciclo de Educación Secundaria de la Comarca de Estepa (Sevilla). Tesis doctoral: Universidad de Granada.

Menéndez, D. y González, C. (2019). Relaciones entre la práctica de actividad física y deportiva, el autoconcepto, la imagen corporal y los hábitos alimentarios en estudiantes de primaria. EBalonmano.com: Revista de Ciencias del Deporte, 15(1), 79-96. 
Mesa, J.L., Ruiz, J., Mula F.J., Gutiérrez, A. y Castillo, M.J. (2002). Hidratación y rendimiento pautas para una elusión efectiva de la deshidratación por ejercicio. Apunts: Educación física y deportes, 70, 26-33.

Muros, J.J., Cofre-Bolados, C., Arriscado, D., Zurita, F., \& Knox, E. (2017). Mediterranean diet adherence is associated with lifestyle, physical fitness, and mental wellness among 10-y-olds in Chile. Nutrition, 35, 87-92. https://doi.org/10.1016/j.nut.2016.11.002

Navarro-Patón, R., Pazos-Couto, J.M., Rodríguez-Fernández, J.E., \& Arufe-Giraldez, V. (2020). Measuring physical self-concept of schoolchildren aged 10 to 16 on physical education lessons. Journal of Human Sport and Exercise, 15(1), 1-13. https://doi.org/10.14198/ihse.2020.151.01

Ortega, F.B., Ruiz, J.R., Labayen, I., Martínez-Gómez, D., Vicente-Rodríguez, G., Cuenca-García, M.; Gracia-Marco, L., Manios, Y., Beghin, L., Molnar, D., Polito, A., Widhalm, K., Marcos, A., GonzálezGross, M., Kafatos, A., Breidenassel. C., Moreno, L.A., Sjöström, M., \& Castillo, M.J. (2014). HELENA project group. Health inequalities in urban adolescents: role of physical activity, diet, and genetics. Pediatric, Apr; 133(4): 884-895. https://doi.org/10.1542/peds.2013-1665

Ortega, M. A., Muros, J. J., Palomares, J., Martín, J.A., \& Cepero, M. (2015). Influence of body mass index on self-esteem of children aged 12-14 years. Anales de Pediatría, 83, 5, 311-317. https://doi.org/10.1016/j.anpedi.2014.11.017

Ortega, M. A., Zurita, F., Cepero, M, \& Campos, B. (2013). La percepción e insatisfacción corporal en el alumnado de Educación Secundaria de la ciudad de Jaén. Revista de investigación en educación, $11(2), 123-139$.

Ovalle, J. (2011). Tratamiento del tema transversal de Educación Ambiental en el alumnado de tercer ciclo de Educación Primaria, de la comarca del Altiplano (Huéscar). Tesis Doctoral: Universidad de Granada.

Palomares-Cuadros, J. (2003). Motivaciones, hábitos físico-deportivos y usos de los espacios del Parque Periurbano Dehesas del Generalife. Tesis Doctoral. Universidad de Granada. Granada: Reprodigital.

Posadas-Kalman, V. (2009). Transmisión y adquisición de valores y actitudes a través del núcleo de contenidos de juegos y deportes en el alumnado de primer y segundo curso de Educación Secundaria Obligatoria de la provincia de Granada. Tesis Doctoral: Universidad de Granada.

Puerto, M., Rivero, D., Sansores, L., Gamboa, L., \& Sarabia, L. (2015). Somnolencia, hábitos de sueño y uso de redes sociales en estudiantes universitarios. Enseñanza e Investigación en Psicología, 20 (2), 189-195.

Rabadán, I.; De Cos-Morente, A.; Benítez, J.D. \& Guillén, M. (2007). Orientaciones teórico-prácticas para la aplicación del calentamiento de competición en deportes de equipo. EFdeportes, Revista Digital, 106. Buenos Aires.

Ramos, P., Jiménez-Iglesias, A., Rivera, F., \& Moreno, C. (2016). Evolución de la práctica de la actividad física en los adolescentes españoles / Physical Activity Trends in Spanish Adolescents. Revista Internacional de Medicina y Ciencias de la Actividad Física y del Deporte/International Journal of Medicine and Science of Physical Activity and Sport, 16(62), 335-353. https://doi.org/10.15366/rimcafd2016.62.010

Rico, C. D. (2017). Inactividad física y sedentarismo en la población española. Revista de Investigación y Educación en Ciencias de la Salud (RIECS), 2(1), 41-48. https://doi.org/10.37536/RIECS.2017.2.1.18

Rodríguez-Bailón, J. D. (2012). La materia de música en primer ciclo de ESO en Antequera y su comarca: fundamentos, motivación y proyección social. Tesis Doctoral: Universidad de Granada. 
Rosa, A., García, E., \& Carrillo, P.J. (2019). Weight status, physical activity and self-concept in primary school children. Journal of Human Sport and Exercise, 14(3), 515-526. https://doi.org/10.14198/ihse.2019.143.03

Ruiz-Ariza, A., Torre-Cruz, M. J., Redecillas-Peiró, M. T., \& Martínez-López, E. J. (2015). Influencia del desplazamiento activo sobre la felicidad, el bienestar, la angustia psicológica y la imagen corporal en adolescentes. Gaceta Sanitaria, 29(6), 454-457. https://doi.org/10.1016/.gaceta.2015.06.002

Ruiz-Ariza, A., De la Torre-Cruz, M., Suárez-Manzano, S. \& Martínez-López, E. (2017). El desplazamiento activo al Centro educativo influye en el rendimiento académico de las adolescentes españolas. Retos, 32, 39-43. https://doi.org/10.47197/retos. v0i32.51614

San Mauro, I., Megías, A., García de Angulo, B., Bodega, P., Rodríguez, P., Grande, G., Micó, V., Romero, E., García, N., Fajardo, D. \& Garicano, E. (2015). Influencia de hábitos saludables en el estado ponderal de niños y adolescentes en edad escolar. Nutrición Hospitalaria, 31(5):1996-2005.

Serrano, M.I. (2003). La eficiencia de la educación y los indicadores de la salud. Revista: A tu salud, 42, 8-12.

Suárez-Ortega, M. (2005). El grupo de discusión: una herramienta para la investigación cualitativa. Barcelona: Laertes.

Taylor, S. J. (1986). Introducción. Ir hacia la gente. Taylor, SJ, Bogdan, R. Introducción a los métodos cualitativos de investigación: la búsqueda de significados. Buenos Aires: Paidós.

Tobar, B. U., Gaete, M. J. F., Lara, M. M., Pérez, A. M., \& Freundt, A. M. R. (2019). Teorías implícitas y modelos de formación subyacentes a la percepción de rol del profesor de Educación Física. Retos: nuevas tendencias en educación física, deporte y recreación, 36, 159-166. https://doi.org/10.47197/retos.v36i36.66532

Valencia-Peris, A., \& Mora, J. L. (2018). Cambios en la representación social de la educación física en la formación inicial del profesorado. Retos: nuevas tendencias en educación física, deporte y recreación, 31, 230-235. https://doi.org/10.47197/retos.v0i34.60144

Villchez-Barroso, G. (2007). Adquisición y mantenimiento de hábitos de vida saludable en los escolares de Tercer Ciclo de Educación Primaria de la comarca granadina de los Montes Orientales y la influencia de la Educación Física sobre ellos. Tesis Doctoral: Universidad de Granada.

Villa-González, E., Ruiz, J. R., \& Chillón, P. (2015). Associations between Active Commuting to School and Health-Related Physical Fitness in Spanish SchoolAged Children: A Cross-Sectional Study. International Journal of Environmental Research and Public Health, 12(9), 10362-73. https://doi.org/10.3390/ijerph120910362

Zueck, M. D. C., García, A. A. R., Villalobos, J. M. R., \& Gutiérrez, H. E. I. (2020). Satisfacción en las clases de Educación Física y la intencionalidad de ser activo en niños del nivel de primaria. Retos: nuevas tendencias en educación física, deporte y recreación, (37), 33-40. https://doi.org/10.47197/retos.v37i37.69027

\section{(9)}

This work is licensed under a Attribution-NonCommercial-NoDerivatives 4.0 International (CC BY-NC-ND 4.0). 


\section{APPENDIX}

Table 4. HAVISAES: Questionnaire of healthy life habits in adolescent students (Cuestionario sobre hábitos de vida saludables en escolares adolescentes).

\begin{tabular}{|c|c|}
\hline \multirow{2}{*}{\multicolumn{2}{|c|}{$\begin{array}{l}\text { HAVISAES. Questionnaire of healthy life habits in adolescent students } \\
\text { Quections/ltem }\end{array}$}} \\
\hline Questions/ltem & \\
\hline \multirow{4}{*}{$\begin{array}{l}\text { 1.- Realization of Physical Activity. } \\
\text { out of class. In your family } \\
\text { environment, who practices } \\
\text { physical or sports activity and how } \\
\text { often? }\end{array}$} & Father \\
\hline & Mother \\
\hline & Siblings \\
\hline & Sisters \\
\hline \multirow{8}{*}{$\begin{array}{l}\text { 2.- What would be the } 3 \text { main } \\
\text { reasons to do physical activity in } \\
\text { your free time? It is better for my } \\
\text { health and I feel good. }\end{array}$} & It is better for my health and I feel good \\
\hline & Have fun \\
\hline & To compete \\
\hline & To keep the line or lose weight \\
\hline & For meeting friends \\
\hline & My parents force me \\
\hline & Improve my fitness (get in shape) \\
\hline & Other motives \\
\hline \multirow{7}{*}{$\begin{array}{l}3 \text { Indicate the } 3 \text { main reasons for not } \\
\text { practicing physical or sports activity } \\
\text { outside of school hours. }\end{array}$} & I do not like \\
\hline & I'm not good at doing sports activities \\
\hline & Lack of time \\
\hline & There are no adequate sports facilities \\
\hline & My parents do not let me \\
\hline & It has no use \\
\hline & Other reasons \\
\hline
\end{tabular}

4.- How many days a week do you do physical or sports activity in your free time? (activities lasting more than 20 minutes and causing fatigue and sweating)

\begin{tabular}{l|l|}
$\begin{array}{l}\text { 5.- What physical activity or sport do } \\
\text { you practice and how often (Outside } \\
\text { of school)? (Answer all of them, } \\
\text { putting the number of days you } \\
\text { practice them). }\end{array}$ & Basketball \\
\cline { 2 - 2 } & Summer Swimming \\
\hline & Soccer or Futsal \\
\hline & Handball \\
\hline & Athletics \\
\hline & Martial Arts \\
\hline & Racket sports \\
\hline & Rhythmic gymnastics \\
\hline & Gymnastics \\
\hline Cycling \\
\hline Volleyball \\
\hline & Dance-Dance-Aerobics \\
\hline & Skateboard/ Skates \\
\hline Canoeing / Sailing \\
\hline & Running (Jogging) \\
\hline & Walk or walk \\
\hline
\end{tabular}




\section{Fitness (Gym)}

Others

6.- How you get to the centre and other places

7.- When you do physical activity, You warm what do you do?

Stretches

You wear sportswear

Your shoes are tied

You hydrate

You wash up when you finish

8.- What degree of interest do you have towards the practice of physical activity and sports?

9.- Do you belong to a sports team, sports school or club?

10.- Do you intend to do or continue to do physical activity or practice any sport in the future?

11.- In your opinion, the interest of your father / mother for you to do physical or sports activity is:

12.- How many days a week do you I'm with family carry out the following activities?

Be with friends

Watch TV

I listen to music

I read books, magazines, newspapers

Cultural activities

Pubs, cafes

Musical instrument

Walk, walk

Internet, computer or game console

Homework or study

Nothing special

Other

13.- How much time do you spend watching television each day?

14.- How many hours do you usually dedicate each day that you play with the computer or video games? (in total, not hours in a row)

15.- How many days a week do you play with the computer or video games?

16.- Have you had any alcoholic beverages throughout your life? (at least 1 glass or glass)

17.- How often do you drink alcoholic beverages throughout the week?

18.- Have you ever gotten drunk?

19.- Of the following, what would be if you drink It makes me feel good

the main reasons to consume alcohol

20.- Of the following, what would be the main reasons for not consuming alcohol.

Drinking is fun

Help make friends

Drinking makes me feel more interesting / important

My friends drink

Older people drink

Is in fashion

Others

It's bad for your health

Alcohol is a drug

Because I play sports

I have no money to buy it 


\begin{tabular}{|c|c|}
\hline & No catches my attention \\
\hline & Because of the pressure of my parents \\
\hline & For complying with the laws \\
\hline & Others \\
\hline 21.- Of the people you know, who & Drinking father \\
\hline drink? & Drinking mother \\
\hline & Siblings / drinkers \\
\hline & Drinking friends \\
\hline 22.- Have you ever tried tobacco? & \\
\hline 23.- What is the frequency with which & you usually smoke? \\
\hline 24.- If you smoke, how many cigarett & es do you smoke per day? \\
\hline 25.- Of the following, indicate the & It makes me feel good \\
\hline main reasons that lead you to smoke & Smoking is fun \\
\hline It makes me feel good. & Help make friends \\
\hline & When smoking I am more interesting \\
\hline & Older people smoke \\
\hline & My friends smoke \\
\hline & Is in fashion \\
\hline & Others \\
\hline 26.- Of the following, indicate the & It is bad for your health \\
\hline main reasons for not smoking it is & Tobacco is a drug \\
\hline bad for your health. & Because I play sports \\
\hline & I have no money to buy it \\
\hline & No catches my attention \\
\hline & Because of the pressure of my parents \\
\hline & For complying with the laws \\
\hline & Others \\
\hline 27.- In your environment, who & Smoking father \\
\hline smokes. & Smoking mother \\
\hline & Smoking siblings \\
\hline & Smoking friends \\
\hline 28.- Have you ever tried other types & fillegal drugs? \\
\hline 29.- What other non-legalized drugs & Marijuana / hashish \\
\hline have you used? & Designer drugs \\
\hline & Amphetamines \\
\hline & Cocaine \\
\hline & Improve performance \\
\hline & Other \\
\hline 30.- Which of these meals do you & Breakfast \\
\hline usually eat? & Playtime \\
\hline & Food \\
\hline & Snack \\
\hline & Dinner \\
\hline & Between hours \\
\hline
\end{tabular}


Table 5. Questions made in the discussion group.

\section{Questions made in the discussion group}

1.- What perception do you think your students have about their health and about the relationship that exists between the practice of physical activity and the benefits it brings to their health? What aspects do you consider making it up?

2.- What healthy habits do your students have the most established, and in which do you think they find it more difficult to acquire or maintain? (Regarding: Food and nutrition; Personal hygiene; Rests and adequate efforts: sleep, nap ...; Postural attitude, sitting, backpacks, heavy loads, etc ...; Negative habits, alcohol, tobacco, drugs, etc.

3.- During breaks: How many days do you usually eat a week? What types of foods are the most consumed?

4.- Are there problems in your centre with anorexia, overweight, obesity, bulimia or bigorexia? Do you feel ready to help prevent, detect, or treat such problems?

5.- Do you think that in general your students like Physical Education as a subject? Do they appreciate or are they aware of how the subject helps them to value and take care of their own body? Are you trying to make them aware of the importance of the subject for health?

6.- From your perception as a Physical Education professional, do you think that your students in general have acquired healthy lifestyle habits, which include a level of adequate physical activity?

7.- Do you think that physical activity and sport is among one of the main options for occupying free time and leisure in the students of your centre?

8.- What do you think would be the main reasons why they do physical activity in their free time? And which ones to abandon or not practice?

9.- What physical activity or sport do they practice and how often (Outside of school)?

10.- What actions, activities and / or projects are being carried out in your centre, to promote health and healthy habits, and which could be carried out in your centre and / or jointly with other centres?

11.- Do you think they are satisfied with their body image?

12.- Any other issue that you want to discuss or include?

\section{@(๑) $\Theta \Theta$}

This work is licensed under a Attribution-NonCommercial-NoDerivatives 4.0 International (CC BY-NC-ND 4.0). 